Arq. Bras. Med. Vet. Zootec., v.67, n.1, p.119-124, 2015

\title{
Double-setting alpha-tricalcium phosphate cement provided with interconection channels in rabbits after enucleation: A potential implant for the anophthalmic socket
}

[Cimento de alfa-fosfato tricálcico de dupla pega munido de canais de interconexão em coelhos enucleados: um possível implante para cavidade anoftálmica]

\author{
D.C. Gomes Junior ${ }^{1}$, A.P. Oriá ${ }^{2} *$, F.A. Dórea Neto ${ }^{3}$, L.A. dos Santos ${ }^{4}$, A. Estrela-Lima ${ }^{2}$, \\ V.F. Barbosa ${ }^{3}$, J.M. Costa Neto ${ }^{2}$, J.L. Laus ${ }^{1}$, C.R. Daleck ${ }^{1}$ \\ ${ }^{1}$ Universidade Estadual Paulista - UNESP - São Paulo, SP \\ ${ }^{2}$ Universidade Federal da Bahia-UFBA, BA \\ ${ }^{3}$ União Metropolitana de Educação e Cultura -UNIME- BA \\ ${ }^{4}$ Universidade Federal do Rio Grande do Sul - UFRGS - Porto Alegre, RS
}

\begin{abstract}
The purpose of this study was to evaluate the macroscopy and microstructure of a double setting alphatricalcium phosphate bone cement sphere provided with interconnection channels (alpha-TCP-i), as well as the integration of the implant with the rabbits' orbital tissue, through macroscopic analysis and histopathology. The external and internal surfaces of the alpha-TCP-i were evaluated macroscopically and by electron microscopy. Twelve New Zealand rabbits received $12 \mathrm{~mm}$ implants of alpha-TCP-i following enucleation of the left eye. The clinical assessment was undertaken daily during the first 15 days, followed by fortnightly assessment until the end of the study period. For the morphological analysis, exenteration was performed in 3 animals per experimental period (15, 45, 90 and 180 days). The external and internal surfaces of the implant appeared solid, smooth and compact, with six channels which interconnected centrally. The micro-architecture was characterized by the formation of columns of hexagonal crystals. No signs of infection, exposure, dehiscence of sutures or extrusion of the implant were noted in any of the animals during the entire period of the study. The morphological evaluation demonstrated the presence of a thin capsule around the implant, from whence appeared fibro-vascular projections, which penetrated it through the interconnecting channels. In the first days after the insertion of the implant, an intense inflammatory reaction was noted. At 180 days, however, there were no signs of inflammation. The alpha-tricalcium phosphate cement implant was well tolerated in this rabbit model and appeared to be relatively inert with some fibrovascular ingrowth through the large channels.
\end{abstract}

Keywords: implant, eye, prosthesis

\section{RESUMO}

Avaliaram-se a macroscopia e a microestrutura de esferas compostas por cimento ósseo de alfa-fosfato tricálcico de dupla pega munido de canais de interconexão (alfa-TCP-i) e a integração do implante ao tecido orbital de coelhos através de análise macroscópica e histopatológica. A superfície interna e externa do alfaTCP-i foi avaliada macroscopicamente e por microscopia eletrônica. Após enucleação do bulbo ocular esquerdo, 12 coelhos da raça Nova Zelândia receberam implantes do alfa-TCP-i com $12 \mathrm{~mm}$ de diâmetro. A avaliação clínica foi realizada diariamente nos primeiros 15 dias e depois a cada quinze dias até o fim do período de estudo. Para análise morfológica, seguiu-se a exenteração de três animais por período experimental (15, 45, 90 e 180 dias). As superfícies externa e interna do implante mostraram-se compactas, sólidas e lisas, com seis canais que se interconectavam centralmente. A microarquitetura caracterizou-se pela formação de colunas de cristais hexagonais. Sinais de infecção, exposição, deiscência de sutura ou extrusão não foram notados em nenhum dos animais durante o período de estudo. A análise morfológica revelou a presença de fina cápsula ao redor do implante de onde surgiram projeções fibrovasculares que o penetraram

Recebido em 22 de agosto de 2013

Aceito em 7 de agosto de 2014

*Autor para correspondência (corresponding author)

E-mail: arianneoria@ufba.br 
através dos canais de interconexão. Nos primeiros dias após a inserção das esferas, notou-se intensa reação inflamatória que se mostrou ausente aos 180 dias. O implante do cimento de alfa-fosfato tricálcico foi bem tolerado em coelhos, mostrou-se relativamente inerte e permitiu a infiltração de tecido fibrovascular através dos canais de interconexão.

Palavras-chave: implante, olho, prótese

\section{INTRODUCTION}

When the eye or its orbital content is removed due to surgical procedures such as enucleation, evisceration or exenteration, an anophthalmic cavity is formed, which is considered aesthetically unpleasant, being associated with a range of appearance-related psychosocial problems and decrease in quality of life for human patients (Wang et al., 2012). Biologically inert compounds such as glass, cartilage, bone, ivory, polymethylmethacrylate, silicone, porous polyethylene and hydroxyapatite (Christmas et al., 1998; Moshfeghi et al., 2000; Amato et al., 2003; Wang et al., 2012) can be used to replace the orbital volume, with consequent improvement in aesthetic appearance (Custer et al., 2003; Jordan et al., 2003; Wang et al., 2012). Even with the many suggested advantages of porous orbital implants, some surgeons continue to use acrylic, glass or silicone spheres, due to the costs of the integrateable implants (Chuah et al., 2004).

It is notable that the calcium phosphate compounds induce a minimal inflammatory reaction and are well tolerated, inert and bioactive (Bertol et al., 2010), having been used in various clinical specialties such as orthopedics, orthodontics and plastic surgery in general (Nakadate et al., 2008; Marukawa et al., 2010). However, its use in ophthalmic plastic surgery is still fairly rare (Oriá et al., 2006).

In face of the existence of various bio-materials which can be used for making ophthalmic implants (Christmas et al., 1998; Moshfeghi et al., 2000; Amato et al., 2003; Wang et al., 2012), the ideal one has still not been defined, so the quest continues for an implant which should be, at the least, less expensive and permit tissue integration. The double setting alpha-tricalcium phosphate bone cement provided with interconnection channels (alpha-TCP-i), in the form of $12 \mathrm{~mm}$ spheres, was assessed, as orbital implants in rabbits submitted to enucleation.

\section{METHODS}

The research protocols were approved by the Ethics and Animal Well-Being Committee of the Faculty of Agricultural and Veterinary Sciences, UNESP, Jaboticabal Campus. The bioethical guidelines of the Association for Research in Vision and Ophthalmology (National Institutes of Health, Publication No. 85-23: Revised, 1985) for the use of animals in vision research were followed.

The spheres used were produced from alpha-TCP created and evaluated in vitro by one of the authors (Santos, 2002). The alpha-TCP powder was homogenized from the aqueous solution of dibasic sodium phosphate. A system of in situ polymerization based in the acrylamide was obtained, as described by one of the authors (Oriá A. P.) (Oriá et al., 2006).

The paste resulting from the homogenization was added to $12 \mathrm{~mm}$ diameter silicon molds. Twentyfour hours later the spheres were removed from the molds and perforated with three orifices of $1.2 \mathrm{~mm}$ diameter, using a perforater provided with a drill bit. These orifices transfixed the implant making six channels with a central intersection. The implants were weighed and the external surfaces were evaluated. In addition, attempts were made to break them between the thumb and forefinger (the pinch test), and the ease with which they could be penetrated with a 25x7 needle was ascertained (Jordan et al., 2000). After fragmentation, the internal surface was evaluated. For the evaluation of the implant's external and internal surfaces with an electron microscope, the fragments were fixed in cylindrical $10 \times 10 \mathrm{~mm}$ (diameter $\mathrm{x}$ height) metal specimen-holders with the aid of adhesive tape. The samples were placed in a metallizer (DESK II, DentonVacuum, USA) for covering with a thin layer of gold (35-nm). For determining the porosity, micrographs were taken with an electron micrograph (JSM: 5410, JEOL, Japan); these were obtained at $15 \mathrm{kV}$ with 50,750 and $1500 \mathrm{x}$ magnification. The measuring bar was 
photographed simultaneously and was 500, 10 and $10 \mu \mathrm{m}$, respectively. A compass was used to measure and convert the size of the pores and crystals (Jordan et al., 2000; Oriá et al., 2006).

The implants were packaged individually and sterilized by autoclave at $132^{\circ} \mathrm{C}$ for 20 minutes at $2.5 \mathrm{~kg} / \mathrm{cm}^{2}$ for use in the animals' orbits. To this end, 12 New Zealand rabbits (Oryctolagus cuniculus), of both sexes, weighing between 2.5 and $3.4 \mathrm{~kg}$, obtained from a rabbit breeding center (Federal University of Recôncavo of Bahia) were used. All the surgical procedures were conducted under isoflurane (Isoflurane, Cristália - Produtos Químicos e Farmacêuticos Ltda., Brazil) general anesthesia. Each animal's left eye was enucleated. The implant was placed in the space formerly occupied by the bulb and fixed by suturing the remnants of the conjunctiva and extraocular muscles with the use of a simple interrupted suture pattern followed by intradermal suture with polyglactin 910 4-0 (Vicryl, Ethicon, USA). Surgeries were performed by the same surgeon.

Immediately after surgery the rabbits received ketoprofen (Ketofen, Meryal Saúde Animal, Brazil) at a dose of $1 \mathrm{mg} / \mathrm{kg}$, subcutaneously, and then at regular 24-hour intervals for the first 3 postoperative days. To provide postoperative comfort to the animals, $0.05 \mathrm{mg} / \mathrm{kg}$ buprenorphine hydrochloride (Tengesic, Schering-Plough, Holanda) was administered subcutaneously at regular 6-hour intervals for the first 5 postoperative days. The surgical surface was cleaned daily with $0.9 \%$ saline at 24 -hour intervals for 15 consecutive days. Clinical evaluation was performed daily for the first 15 postoperative days and then at 15-day intervals until the end of the experimental period always by the same professional.

After euthanizing with an overdose of barbiturates 3 animals were exenterated at 15 , 45, 90 and 180 days performed by the same surgeon. The material was immersed in a $10 \%$ formalin solution. For the histo-pathological processing, the tissue cover was separated, and after macroscopic evaluation, included in paraffin using routine techiniques. Paramedial sagittal 3 to $4 \mu \mathrm{m}$ thick sections were taken and stained with hematoxylin and eosin (HE).

\section{RESULTS}

The mean weight of the alpha-TCP-i spheres was 0.91g. The implants were solid, smooth and compact, with scattered pores between which there was no communication. Six channels were visible on the external surface (Figure 1A). The central intersection could be observed internally (Figure 1B). The pinch test was negative, and it was not possible to penetrate the implant with a $25 \times 7$ needle. The microarchitecture was characterized by the presence of hexagonal crystals measuring from 1.3 to $5.5 \mu \mathrm{m}$ and micropores between 0.5 and $5.6 \mu \mathrm{m}$ (Figure 2).

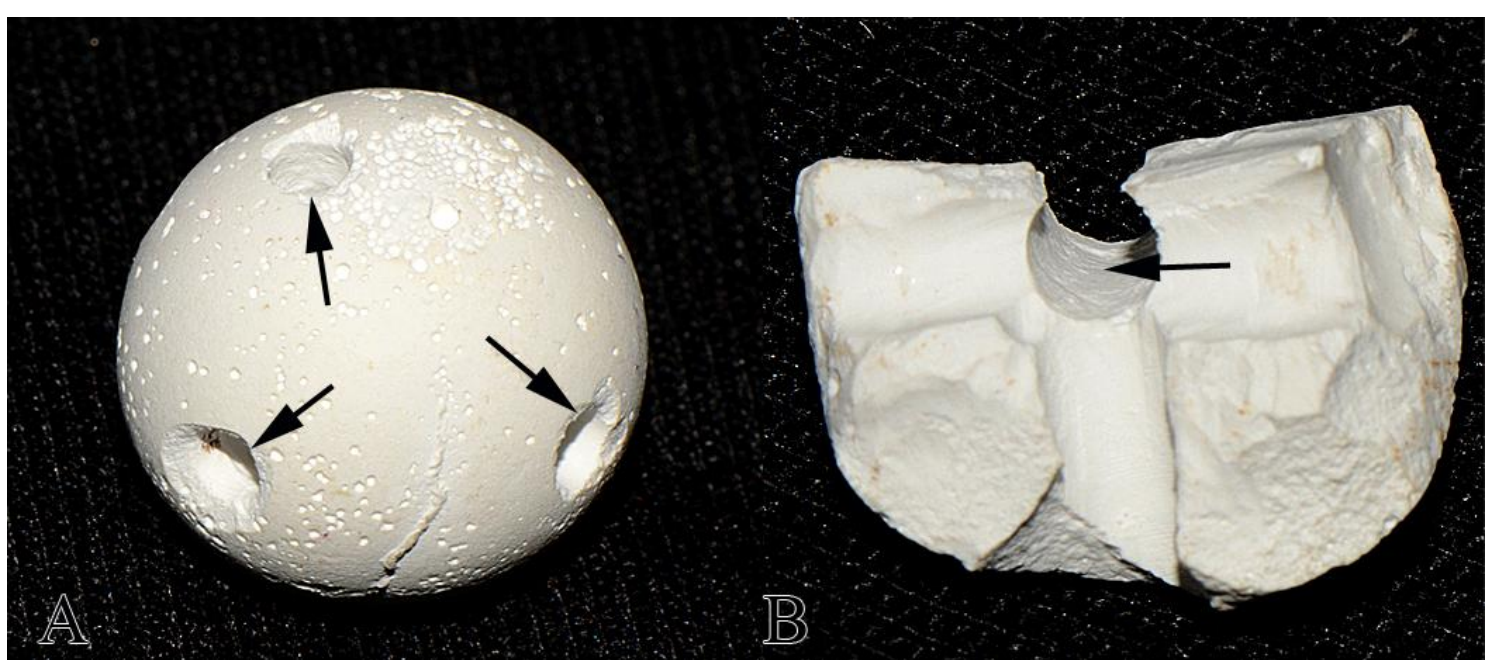

Figure 1. Surface of the double-setting alpha-tricalcium phosphate bone cement of interconnecting channels implant. A. External. B. Internal. 


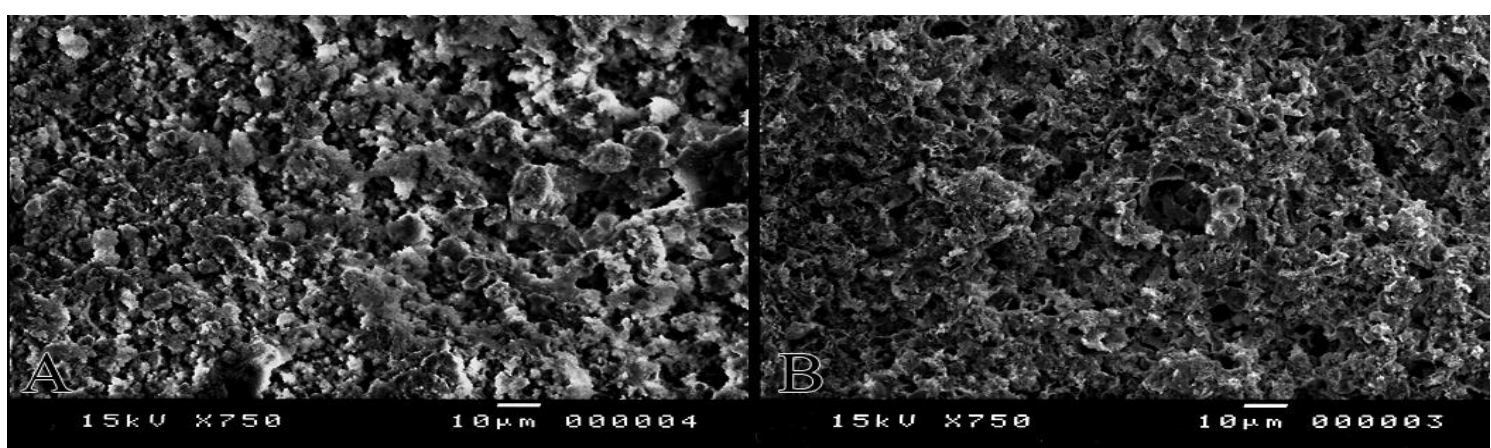

Figure 2. Scanning electron microscopy of the double-setting alpha-tricalcium phosphate bone cement of interconnecting channels implant (magnification X750). A. External surface. B. Internal surface.

None of the animals were systemic and no local complications observed, related to the implants or not. The implants were removed with difficulty from the tissue covering which surrounded them, due to the infiltration of fibrovascular tissue through the interconnecting channels (Figure 3A and 3B). On the surface of the tissue covering in contact with the implant, fibrovascular projections were observed, associated with the intense mixed diffuse inflammatory infiltrate, predominantly lymphohistiocytic, accompanied by foreign-body giant cells at 15 days (Figure 3C). At 45 days one can observe the presence of granulation tissue beyond those found at 15 days, however, with moderate inflammatory intensity. At 90 days, one can observe focal lymphoplasmacytic infiltrate, associated with eosinophiles and mild edema, congestion, foci of hemorrhage, and focal hypertrophy of secretory cells was noted. Congestion of vascular structures on the slide itself and the absence of inflammatory reaction were observed at 180 days (Figure 3D).

\section{DISCUSSION}

With the exception of the conical synthetic hydroxyapatite implants (Kundu et al., 2005), which were perforated to permit the suturing of the extra-ocular muscles, there are no references in the literature on the use of implants in the form of spheres in the orbital cavity provided with large channels for interconnection, with the objective of permitting the infiltration of fibrovascular tissue, with exception of the recent study using perforated acrylic orbital implants in eviscerated rabbits (Miyashita et al., 2013).

The double setting alpha-tricalcium phosphate bone cement used as an ocular implant in eviscerated rabbits (Oriá et al., 2006), behaved in an inert and non-integrable manner. The integrable implant provides adequate ocular motility and later coupling of the prosthesis. The tissues' integration with the ophthalmic implant depends on factors such as the biomaterial used and its physical, chemical and biological features (Jordan et al., 2002), size and quantity of pores, type of material used to wrap the implant and the reaction of the host tissue (Rubin et al., 1994). Due to the infiltration of the fibrovascular tissue in the sphere, ascertained in this study, the implant can be characterized as integrable.

The majority of implants reported, such as the Bio-Eye, the $\mathrm{FCl}_{3}$, the Alumina and the Molteno M-Sphere have multiple interlinked pores, which permit the integration of fibrovascular tissue from the host, which reduces the risk of extrusion (Jordan et al., 2000; Jordan et al., 2002). This fact was not noted in the present study, as the electron microscope scan of the sphere revealed only surface micropores of 0.5 to $5.6 \mu \mathrm{m}$, which did not interconnect. Tissue infiltration can be observed in micropores bigger than $5 \mu \mathrm{m}$, as observed in the evaluation of the national hydroxyapatite, which permitted the migration of fibrovascular tissue to the interior of the sphere in micropores of 5-10 $\mu \mathrm{m}$ (Jordan et al., 2000). It was observed that even in the absence of interlinked pores, the presence of channels for interconnection made the infiltration of host tissue possible, which contributed to the absence of complications reported by other studies, such as ocular discharge, pain, exposure, infection, dehiscence of the sutures and extrusion (Molteno et al., 1973; Toft et al., 2010; Kanamura et al., 2012). 


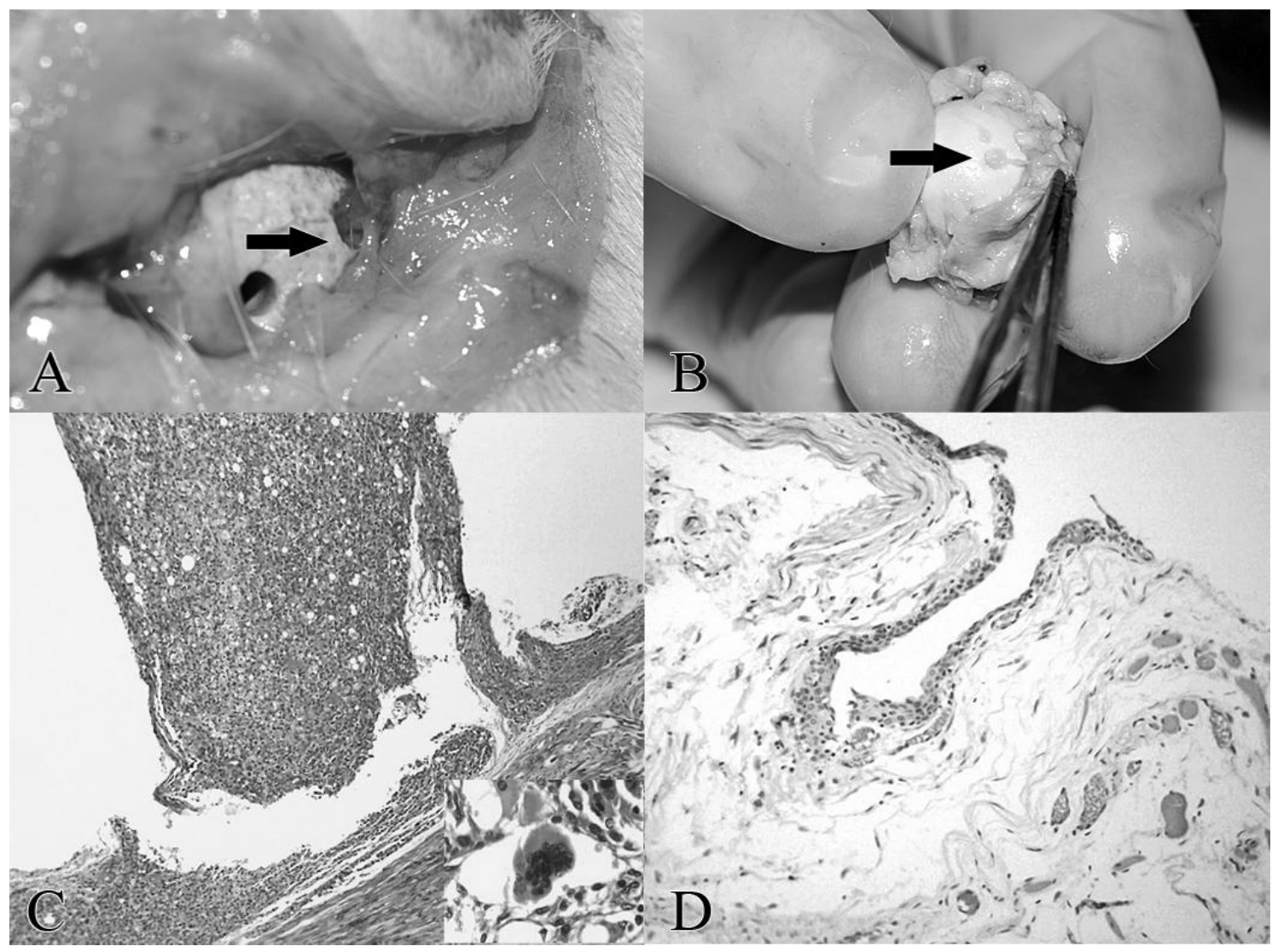

Figure 3. Double-setting alpha-tricalcium phosphate bone cement with interconnecting channel implant after 15 and 180 days of surgery. Note the fibrovascular projections after 15 (A) and 180 (B) days of surgery (arrow). C. Fibrovascular projection associated with the intense mixed diffused inflammatory infiltrate, predominantly lymphohistiocytic, on the surface of the tissue cap in contact with the implant (HE, 50X) accompanied by foreign body giant cells (HE, detail 100X) at 15 days post-surgery. D. Congestion of vascular structures and absence of inflammatory reaction (HE, X100) at 180 days post surgery.

Mixed inflammation with accumulation of lymphocytes, histiocytes and granulocytes after more than six months since the placing of the implant was verified in human patients who received implants of hydroxyapatite and porous polyethylene (Toft et al., 2010). In this work, an intense mixed inflammatory infiltrate was only observed in the initial periods (15 days), with a gradual reduction in the inflammatory response, which was absent at 180 days, which is alike to the histopathological findings of the bioglass and bioceramic cones used in rabbits submitted to evisceration (Brandão et al., 2012).

Due to the lack of the ideal implant, considered biocompatible, durable and that allows adequate tissue integration, adaptation of the peg system and good prosthetic mobility, new researches are justified in pursuing this implant. The alphaTCP- $\mathrm{i}$ is easy to manufacture, resistant, has simple handling, presents a low cost when compared to other biomaterials, and the way it was designed allowed tissue infiltration.

\section{CONCLUSION}

It should be emphasized that further studies are required in order to adapt the peg system and ocular prosthesis for prosthetic mobility evaluation. Thus the implant of double-setting alpha-tricalcium phosphate bone cement with interconnecting channels could be a feasible option for humans but can already be used for veterinarian patients to replace the volume lost after enucleation and exenteration procedures. 


\section{ACKNOWLEDGEMENTS}

The authors acknowledge FAPESB (5881-2009) for financial support

\section{REFERENCES}

AMATO, M.M.; BLAYDON, S.M.; SCRIBBICK, F.W. et al. Use of bioglass for orbital volume augmentation in enophthalmos: a rabbit model (Oryctolagus cuniculus). Ophthal. Plast. Reconstr. Surg., v.6, p.455-65, 2003.

BERTOL, L.S.; ECOBAR, C.S.; KINDLAIN, J.R.W. Projeto, fabricação e avaliação de implantes craniofaciais personalizados: proposta de utilização de materiais combinados. Rev. Bras. Eng. Biomed., v.2, p.79-89, 2010.

BRANDÃO, S.M.; SCHELLINI, S.A.; MORAES, A.D. et al. Biocompatibility analysis of bioglass ${ }^{\circledR}$ 45S5 and biosilicate ${ }^{\circledR}$ implants in the rabbit eviscerated socket. Orbit., v.3, p.143-149, 2012.

CHRISTMAS, N.J.; GORDON, C.D.; MURRAY, T.G. et al. Intraorbital implants after enucleation and their complications: a 10-year review. Arch. Ophthalmol., v.9, p.1199-1203, 1998.

CHUAH, C.T.; CHEE, S.P.; FONG, K.S. et al. Integrated hydroxyapatite implant and non-integrated implants in enucleated Asian patients. Ann. Acad. Med. Singap., v.33, p.477-483, 2004.

CUSTER, P.L.; KENNEDY, R.H.; WOOG, J.J. et al. Orbital implants in enucleation surgery: a report by the American Academy of Ophthalmology. Ophthalmol. v.10, p.2054-2061, 2003.

JORDAN, D.R.; BROWNSTEIN, S.; GILBERG, S. et al. Investigation of bioresorbable orbital implant Ophthal. Plast. Reconstr. Surg., v.5, p.324-348, 2002.

JORDAN, D.R.; GILBERG, S.; MAWN, L.A. The bioceramic orbital implants. Experience with 107 implants. Ophthal. Plast. Reconstr. Surg., v.2, p.128135, 2003.

JORDAN, D.R.; HWANG, I.; MCEACHREN, T. et al. Brazilian hydroxyapatite implant. Ophthal. Plast. Reconstr. Surg., v.5, p.363-369, 2000.

KANAMURA, M.S.; PADOVANI, C.R.; PEREIRA, E.J. et al. Estudo comparativo entre as esferas de silicone gelatinosas e rígidas em cavidade eviscerada de coelho. Arq. Bras. Oftal., v.75, p.197-201, 2012.
KUNDU, B.; SINHA, M.K.; MITRA, S. et al. Synthetic hydroxyapatite-based integrated orbital implants: A human pilot trial. Indian J. Ophthal., v.53, p.235-241, 2005.

MARUKAWA, K.; UEKI, K.; OKABI, K. et al. Use of self-setting a-tricalcium phosphate for maxillary sinus augmentation in rabbit. Clin. Oral. Implants Res., v.6, p.606-612, 2010.

MIYASHITA, D.; CHAHUD, F.; SILVA, G.E.B. et al. Tissue Ingrowth Into Perforated Polymethylmethacrylate Orbital Implants: An Experimental Study. Ophthal. Plast. Reconstr. Surg., v.3, p.160-163, 2013.

MOLTENO, A.C.; VAN ROOYEN, J.H.; ANCKER, E. "Physiological" orbital implant. Br. J. Ophthalmol., v.8, p.615-621, 1973.

MOSHFEGHI, D.M.; MOSHFEGHI, A.A.; FINGER, P.T. Enucleation. Surv. Ophthalmol,. v.4, p.277-301, 2000

NAKADATE, M.; AMIZUKA, N.; LI, M. et al. Histological Evaluation on Bone Regeneration of Dental Implant Placement Sites Grafted With a SelfSetting a-Tricalcium Phosphate Cement. Micros. Res. Tech., v.2, p.93-104, 2008

ORIÁ, A.P.; NETO, F.A.; LAUS, J.L. et al. Evaluation of a double-setting alfa-tricalcium phosphate cement in eviscerated rabbit eyes. Ophthal. Plast. Reconstr. Surg., v.2, p.126-130, 2006.

RUBIN, P.A.; POPHAM, J.K.; BILYK, J.R. et al. Comparison of fibrovascular ingrowth into hydroxyapatite and porous polyethylene orbital implants. Ophthal. Plast. Reconstr. Surg., v.2, p.96103, 1994.

SANTOS, L.A. dos. Desenvolvimento de cimento de fosfato de cálcio reforçado por fibras pra o uso na área médico-odontológica. 2002. 275f. Tese (Doutorado em Engenharia de Biomateriais) Universidade Estadual de Campinas, São Paulo.

TOFT, P.B.; RASMUSSEN, M.R.L.; PRAUSE, J.U. One-stage explant-implant procedure of exposed porous orbital implants. Acta ophthalmol., v.3, p.210214, 2010.

WANG, J.; ZHANG, H.; CHEN, W.; LI, G. The Psychosocial Benefits of Secondary Hydroxyapatite Orbital Implant Insertion and Prosthesis Wearing for Patients With Anophthalmia. Ophthal. Plast. Reconstr. Surg., v.5, p.324-327, 2012. 